Jpn. J. Limnol., 58 : 241-260, 1997

\title{
Relationship of Internal Waves with Tide and Wind Drift Effects and Propagation of Internal Kelvin Waves in Brackish Lake Nakaumi
}

\author{
Tomoyasu FuJII
}

\begin{abstract}
An internal wave with an amplitude of about $2 \mathrm{~m}$ driven by tidal and wind drift effects is frequently observed in Lake Nakaumi. Highly saline water of the lower layer creeps up toward the lake coast driven by the internal waves, greatly affecting the general water quality and biological environment not only of Lake Nakaumi but also of the Ohashi River and Lake Shinji because of the upstream flow of highly saline water. In this paper, the effects of tides and wind drift on the internal waves were evaluated with the results of observations made with neutral buoys.

Tides appear to clearly affect the internal oscillations only at the observation point near the Nakaura water gate ; the internal oscillation near the gate occurs with a phase lag of $1 \mathrm{hr}$ after a water level change. The effect of wind drift on internal oscillation is clearly apparent near the upwind and downwind coasts. The halocline in the eastern littoral region of the downwind coast descends about $2.5 \mathrm{hr}$ after a westerly wind starts to blow, while the halocline in the western littoral region of the upwind side rises about $3 \mathrm{hrs}$ after the wind comes up.

These phenomena agree well with the relationship between wind drift and inclination of the halocline in a two-layer lake model. The effect of wind drift on internal oscillation is greater than tidal effects, except for the observation point near the Nakaura water gate, because a dominant wind usually blows toward the east in Lake Nakaumi during summer. Cross correlation of observed displacement of the halocline between neighboring points and internal phase speeds calculated from density stratification conditions in Lake Nakaumi suggest that an internal Kelvin wave propagates counterclockwise along the coast.
\end{abstract}

Key words : brackish lakes, internal oscillation, internal Kelvin waves, tide and wind drift effects

\section{INTRODUCTION}

Lake Nakaumi is located in the eastern part of Shimane Prefecture in Japan. 
The lake (water area, $86.8 \mathrm{~km}^{2}$; mean water depth, $5.4 \mathrm{~m}$; maximum water depth, $16.0 \mathrm{~m}$ ) is connected with the Sea of Japan by the Sakai Channel (length, $7.5 \mathrm{~km}$ ), and with Lake Shinji (water area, $79.2 \mathrm{~km}^{2}$; mean water depth, $4.5 \mathrm{~m}$; maximum water depth, $6.4 \mathrm{~m}$ ) by the Ohashi River (length, $7.5 \mathrm{~km}$ ). (Fig. 1)
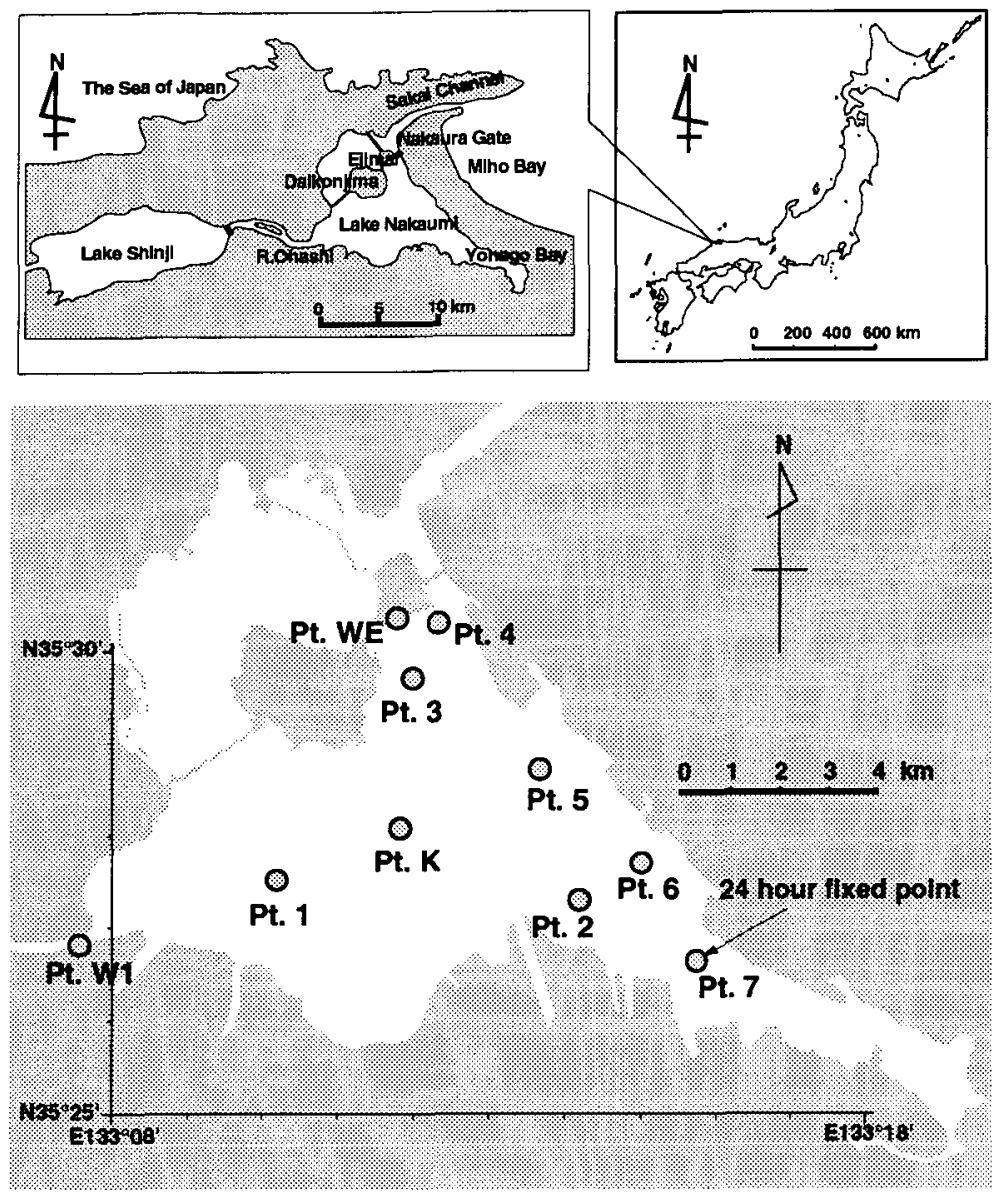

Fig. 1. Observation points in Lake Nakaumi.

Pt. 1, 2, 3, 4, 5 and 6 are internal wave observation points where neutral buoys were deployed; Pt. 7 is a $24 \mathrm{hr}$ fixed observation point; and Pt. W1 and WE are water-level gauge stations.

Pt. 1 : lat $35^{\circ} 27^{\prime} 30^{\prime \prime} \mathrm{N}$, long $133^{\circ} 09^{\prime} 58^{\prime \prime} \mathrm{E}$

Pt. 2 : lat $35^{\circ} 27^{\prime} 23^{\prime \prime} \mathrm{N}$, long $133^{\circ} 13^{\prime} 17^{\prime \prime} \mathrm{E}$

Pt. 3 : lat $35^{\circ} 29^{\prime} 50^{\prime \prime} \mathrm{N}$, long $133^{\circ} 12^{\prime} 11^{\prime \prime} \mathrm{E}$

Pt. 4 : lat $35^{\circ} 30^{\prime} 13^{\prime \prime} \mathrm{N}$, long $133^{\circ} 12^{\prime} 18^{\prime \prime} \mathrm{E}$

Pt. 5 : lat $35^{\circ} 28^{\prime} 38^{\prime \prime} \mathrm{N}$, long $133^{\circ} 13^{\prime} 44^{\prime \prime} \mathrm{E}$

Pt. 6 : lat $35^{\circ} 27^{\prime} 41^{\prime \prime} \mathrm{N}$, long $133^{\circ} 15^{\prime} 02^{\prime \prime} \mathrm{E}$

Pt. 7 : lat $35^{\circ} 26^{\prime} 36^{\prime \prime} \mathrm{N}$, long $133^{\circ} 15^{\prime} 34^{\prime \prime} \mathrm{E}$ 
In Lake Nakaumi, a stable stratification with a halocline is formed by the density difference between seawater flowing in through the Sakai Channel from the Sea of Japan and freshwater from the many rivers which flow into the lake. This stable two-layer structure produces a peculiar aquatic environment.

The density difference between the upper and lower layers in brackish lakes is much larger than that in freshwater lakes. Furthermore, it takes more energy to induce the inclination of the interface in brackish lakes than freshwater lakes, although brackish lakes maintain internal oscillation for a longer time.

The highly saline water mass below this halocline can easily become anoxic due to both weak vertical mixing between the upper and lower layers which suppresses the oxygen transport from the surface layer, and to the large oxygen demand by suspended particles and dissolved matter in the lower layer and bottom sediments.

It is well known that internal waves with a large amplitude are often driven by tidal and wind drift effects in Lake Nakaumi. Moreover, creeping up of highly saline water of the lower layer driven by internal waves greatly affects the general water quality and biological environment not only of Lake Nakaumi, but also of the Ohashi River and Lake Shinji due to the upstream flow of highly saline water driven by internal waves (FUJII et al., 1996).

This paper considers how tidal or wind drift effects influence the occurrence and propagation of internal wave in Lake Nakaumi based on observations using neutral buoys.

\section{MATERIAL AND METHODS}

We measured the movements and fluctuations of the anoxic water mass driven by internal waves in brackish Lake Nakaumi with neutral buoys from 8 to 17 July, 1995 and from 1 to 5 July, 1996.

These observations were carried out in summer, when stable stratification occurs and a land-sea breeze blows periodically.

We deployed neutral buoys to measure not only the internal oscillations at a fixed point, but also the propagation characteristics of the internal waves caused by the earth's rotation. We set the neutral buoys at 3 points (Pts. 1, 2 and 3) forming an equilateral triangle in July 1995, and at 3 other points (Pts. 4, 5 and 6) on a line parallel to the Yumigahama Peninsula in July, 1996 (Fig. 1). After measuring the depth of the halocline, we chose observation points at 6 or $7 \mathrm{~m}$ in depth.

The neutral buoy is a very simple and effective instrument for measuring internal waves over a long period in such brackish water. Details of the structure of the neutral buoys and the observation methods used were reported in a previous paper (FUJII et al., 1996), and are omitted here.

We were provided with hourly observational data of wind velocity at the center of the lake (Pt. K) by the Izumo Construction Office of the Ministry of Construction. We used the water-level data recorded every $5 \mathrm{~min}$ by a 
gauge which the Shinjiko-Nakaumi Brackish Lake Institute installed at Pt. W1 (see Fig. 1). These data were more easily available and show almost identical patterns, with small phase differences, to the Ministry of Construction data.

\section{RESULTS}

\section{Effect of tide on internal oscillation}

It is thought that tidal oscillations greatly impact internal oscillations in brackish lakes.

We compared water level changes with internal oscillations at each sampling point in the lake.

Remarkably, in July 1995, the internal oscillation at Pt. 3 (the nearest sampling point to the Sea of Japan) occurred with a small phase lag from the water level change, while the internal oscillations at the other points (Pts. 1 and 2) exhibited more substantial lags (Fig. 2).

We correlated the water level change at Pt. W1 with the internal oscillation at each point to examine these results quantitatively (Fig. 4).

Figure 4 shows that the internal oscillation generated by tidal effect at WE propagated to Pt. 3 with a phase lag of $1.0 \mathrm{hr}$, from Pt. 3 to Pt. 1 with a phase lag of $6.0 \mathrm{hrs}$, and from Pt. 1 to Pt. 2 with a phase lag of $12.0 \mathrm{hrs}$. Consequently, we found that the internal oscillation generated by tidal oscillation propagated counterclockwise along the lake coast. We also correlated water level changes in $\mathrm{Pt}$. WE with internal oscillations at each point along the lake coast (Pts. 4, 5 and 6) to investigate the relationship between tide and internal waves in 1996 (Figs. 3 and 5).

However, as shown in Figures 2 and 3, the phase lag between tidal and internal oscillations was almost undetectable during the 1995 observation period, because a northwesterly wind had constantly blown and the wind drift effect was weak at Pt. 1 near the Nakaura Water Gate. On the other hand, the correlation between tidal and internal oscillations at Pt. 4 was low during the 1996 observation period when a southwesterly or northeasterly wind had blown. This is because Pt. 4 is situated in the northeast corner of the lake, and a southwesterly or northeasterly wind brings about a large wind drift effect there, partly masking the tidal effect.

Thus, the results presented above suggest that tide is a significant cause of internal waves only near the Nakaura water gate currently inactive, the entrance to Lake Nakaumi, and the tidal effects were observed clearly only when the wind drift effect was weak.

\section{Effect of wind drift on internal oscillation}

It is well known that wind drift forces also affect internal waves, as shown by analytical studies using a model of a circular lake by CSANADY (1967, $1968 \mathrm{a}, 1968 \mathrm{~b}$ ). In those studies, the thermocline near the downwind coast descends $4 \mathrm{hrs}$ after a wind starts to blow. However, the impact of wind drift on internal waves in a noncircular, brackish lake such as Lake Nakaumi 


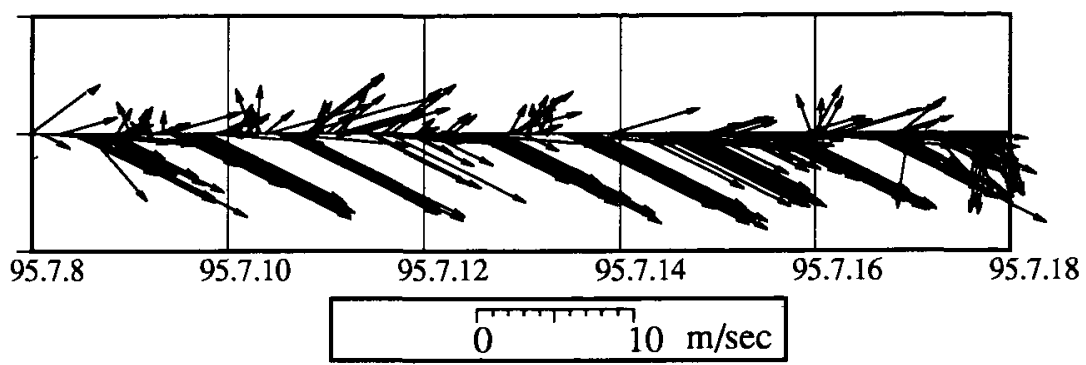

홍

(a) wind velocity

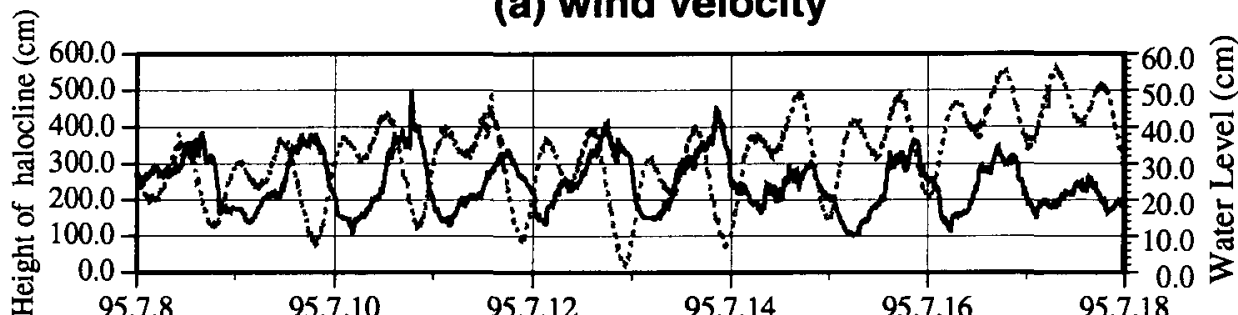

(b) Pt. 1

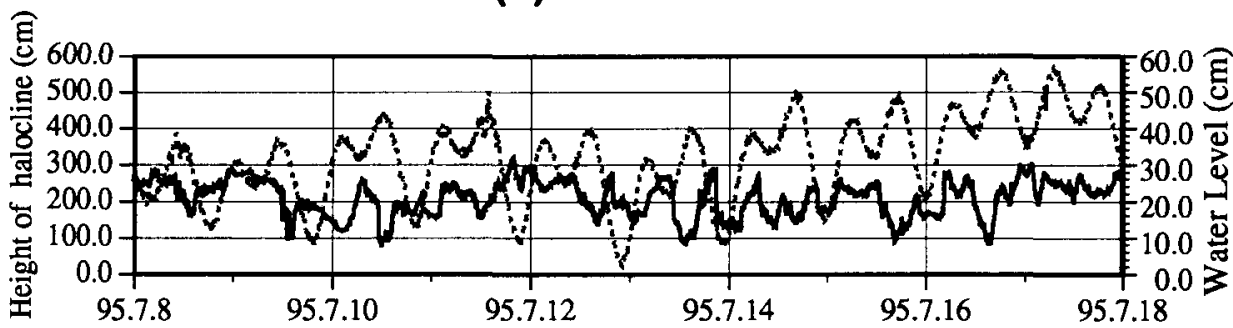

(c) Pt. 2

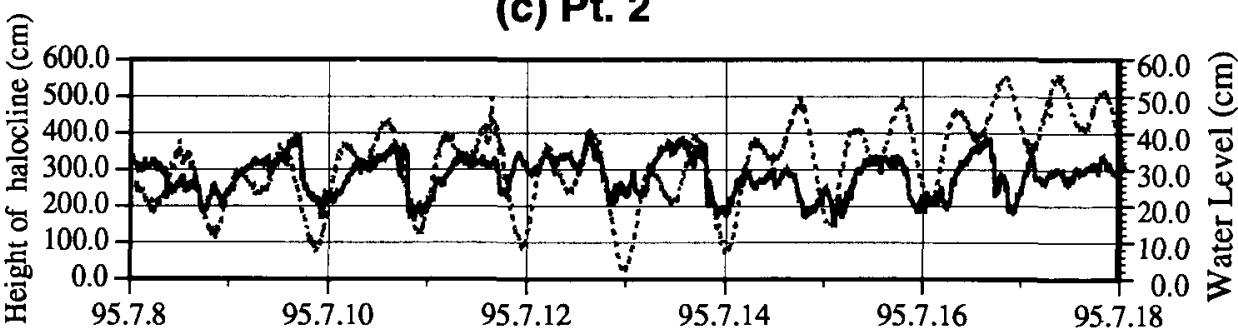

(d) Pt. 3

\section{Internal Oscillation \\ Water level change}

Fig. 2. Changes in the height of the halocline from the bottom showing internal oscillation and water level changes in Lake Nakaumi from 8 to 17 July 1995.

(a) wind velocity, (b) Pt. 1, (c) Pt. 2, (d) Pt. 3. 

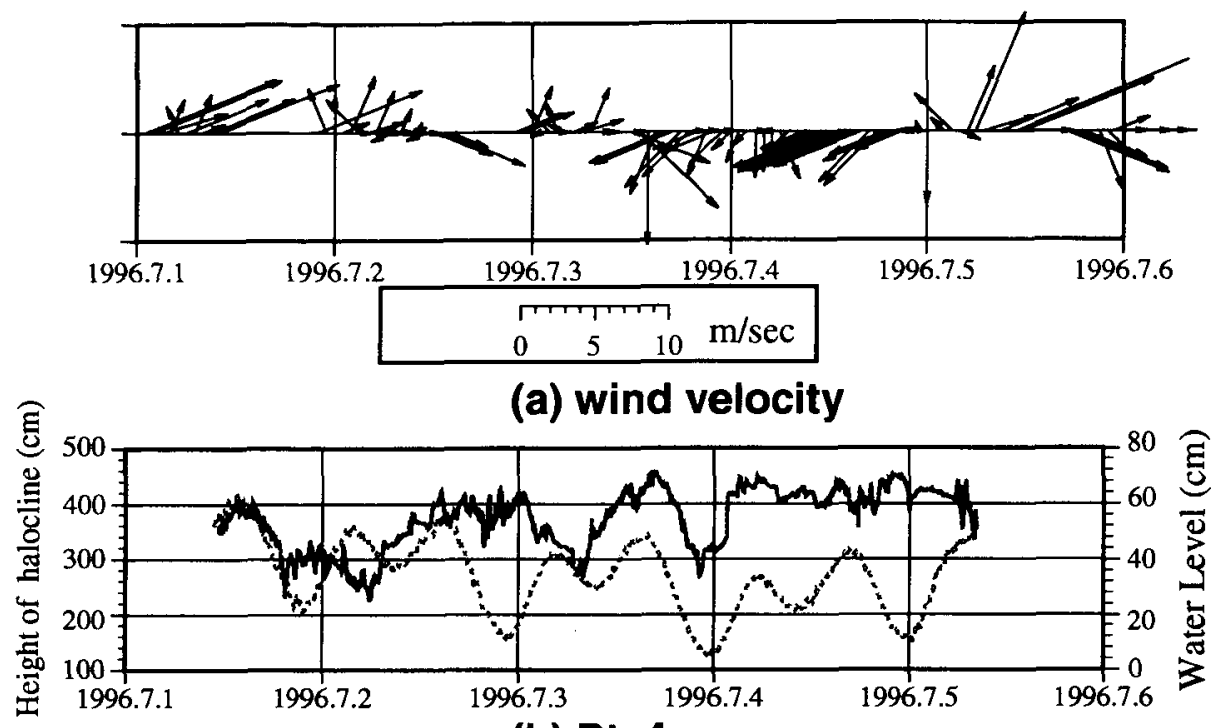

(b) Pt. 4

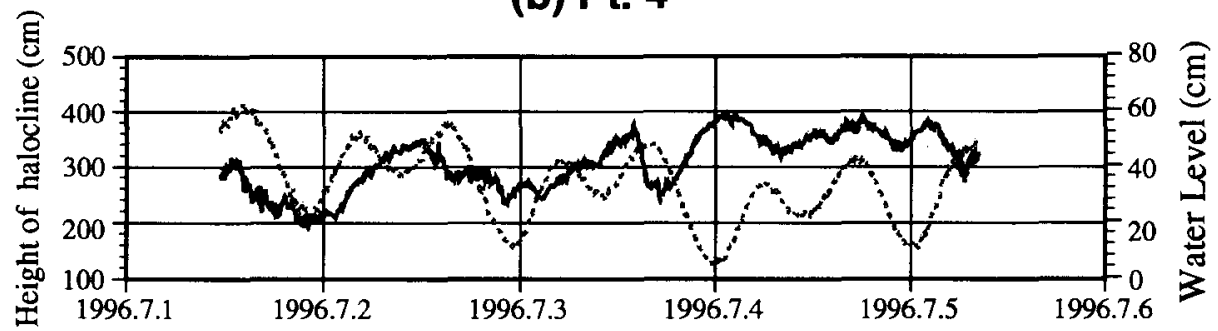

(c) Pt. 5

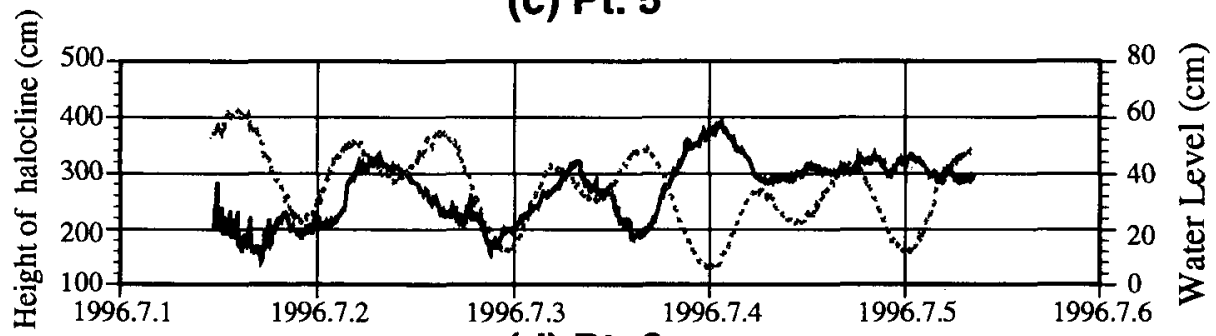

(d) Pt. 6

\section{Internal Oscillation}

Water level change

Fig. 3. Changes in the height of the halocline from the bottom showing internal oscillation and water level changes in Lake Nakaumi from 1 to 5 July 1996.

(a) wind velocity, (b) Pt. 4, (c) Pt. 5, (d) Pt. 6. 


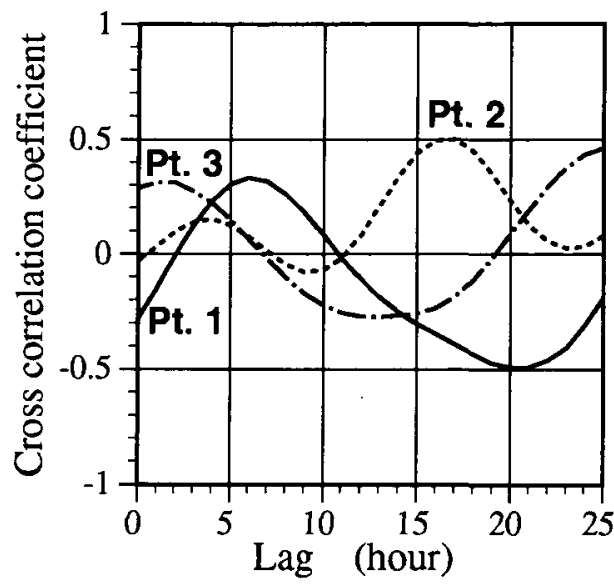

Pt. 1 -.... Pt. 2 -.- Pt. 3

Fig. 4. Cross correlation coefficient between water level change and change in the height of the halocline from 8 to 17 July 1995 .

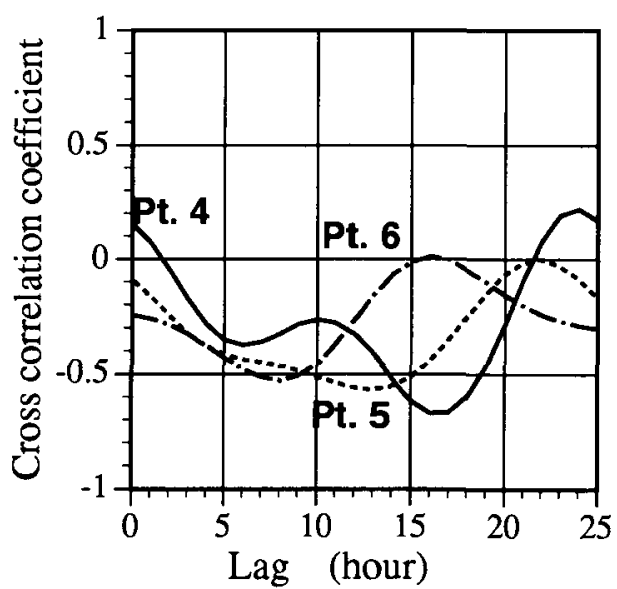

Pt. 4 -... Pt. 5 -.- Pt. 6

Fig. 5. Cross correlation coefficient between water level change and change in the height of the halocline from 1 to 5 July 1996. 
remains unknown. Therefore, studies on the delay of halocline descent after a wind starts to blow are very important for understanding the movement of anoxic water driven by the internal oscillations in Lake Nakaumi. During our observations in July, 1995 and 1996, we presumed that an internal oscillation along the east-west axis occurred because a dominant wind blew east or west over the lake (Fig. 6). We compared the east-west component of wind velocity (hereafter called east-west wind speed) with the internal oscillation at each point. A positive value of east-west wind speed corresponds to wind blowing from west to east.

During July 1995, the height of the halocline at Pt. 2 was at a minimum when the east-west wind speed reached a maximum; in other words, the fluctuations in east-west wind speed and the internal oscillation at Pt. 2 were opposite in phase (Fig. 7). In contrast, the fluctuation in the halocline at Pt. 1 and the east-west wind speed were in phase.
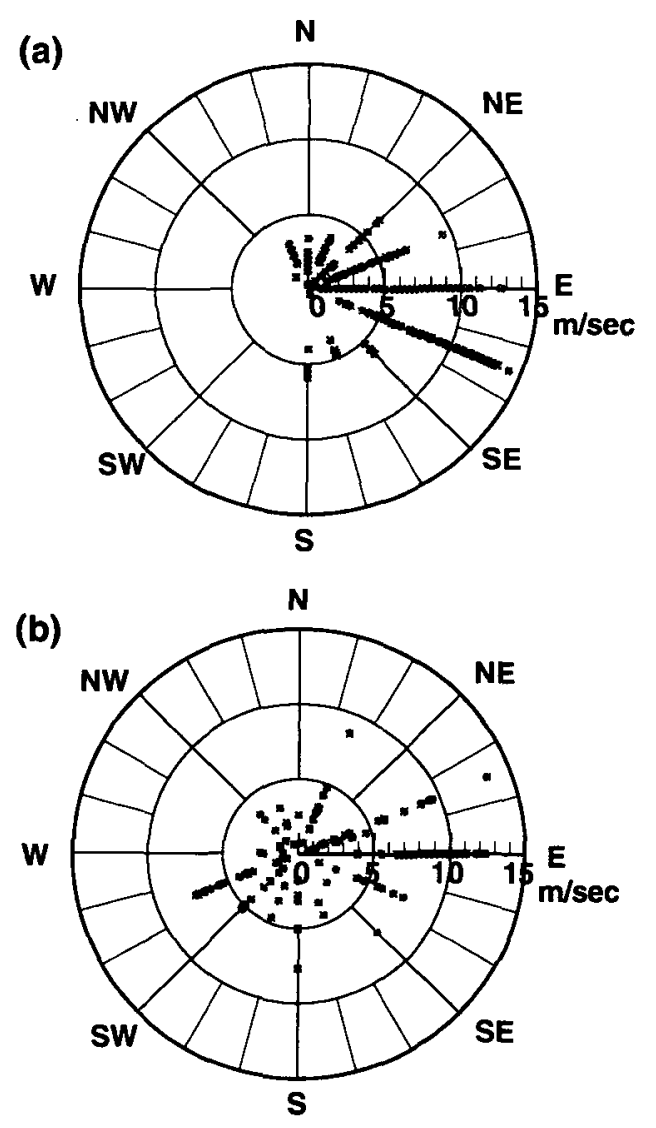

Fig. 6. Distribution of wind speed and direction at the center of Lake Nakaumi (Pt.K).

(a) 8 to 17 July 1995, (b) 1 to 5 July 1996. 
These phenomena are consistent with the relationship between wind drift and inclination of the halocline in a two-layer model of a lake, as shown in Figure 8.

To examine these relations in detail, we correlated the fluctuation of east-west wind speed at $\mathrm{Pt}$. $\mathrm{K}$ with the internal oscillation at each point.

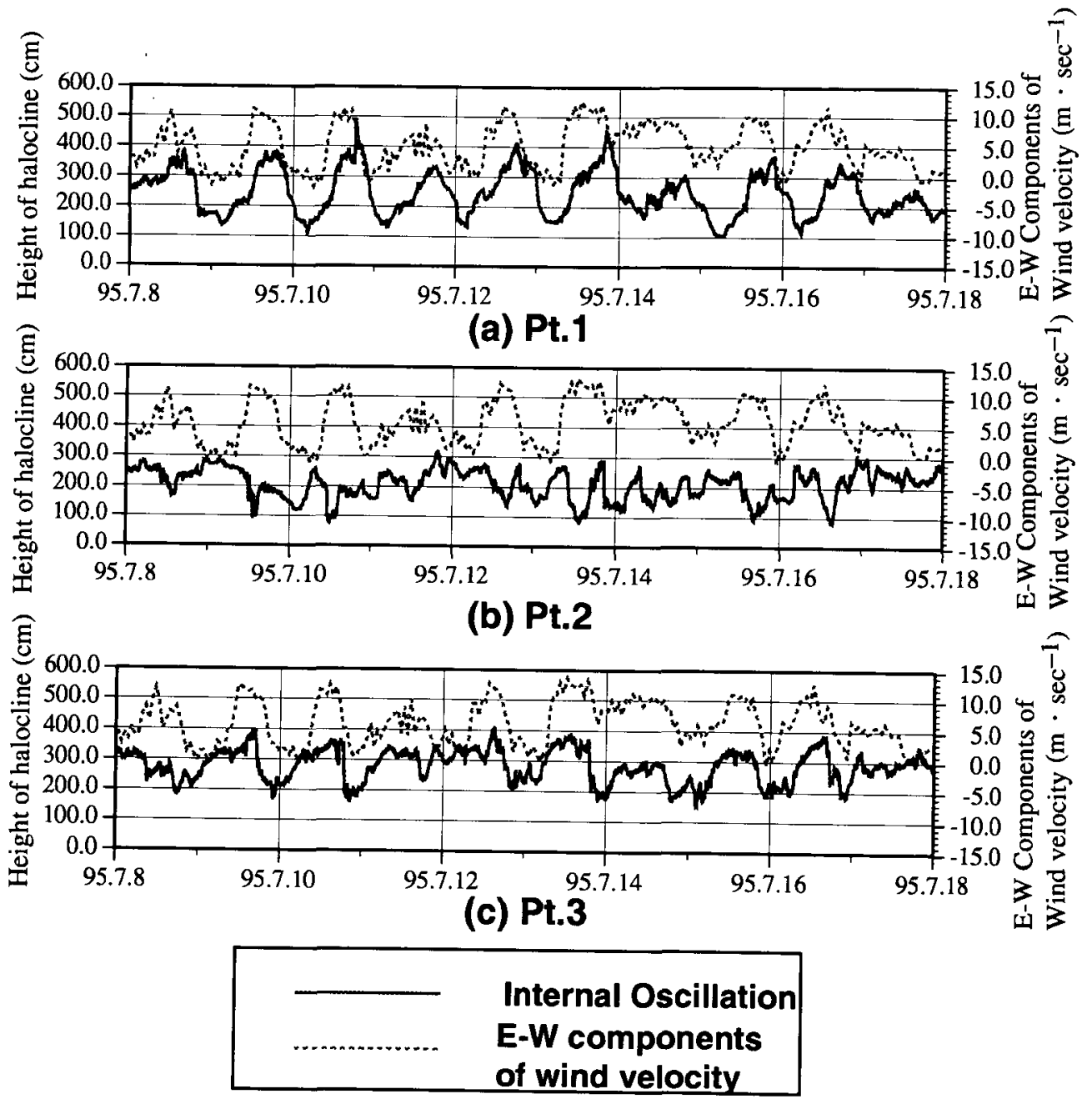

Fig. 7. Changes in the height of the halocline from the bottom showing internal oscillation and the E.W components of wind velocity from 8 to 17 July 1995 .

(a) Pt. 1, (b) Pt. 2, (c) Pt. 3. 


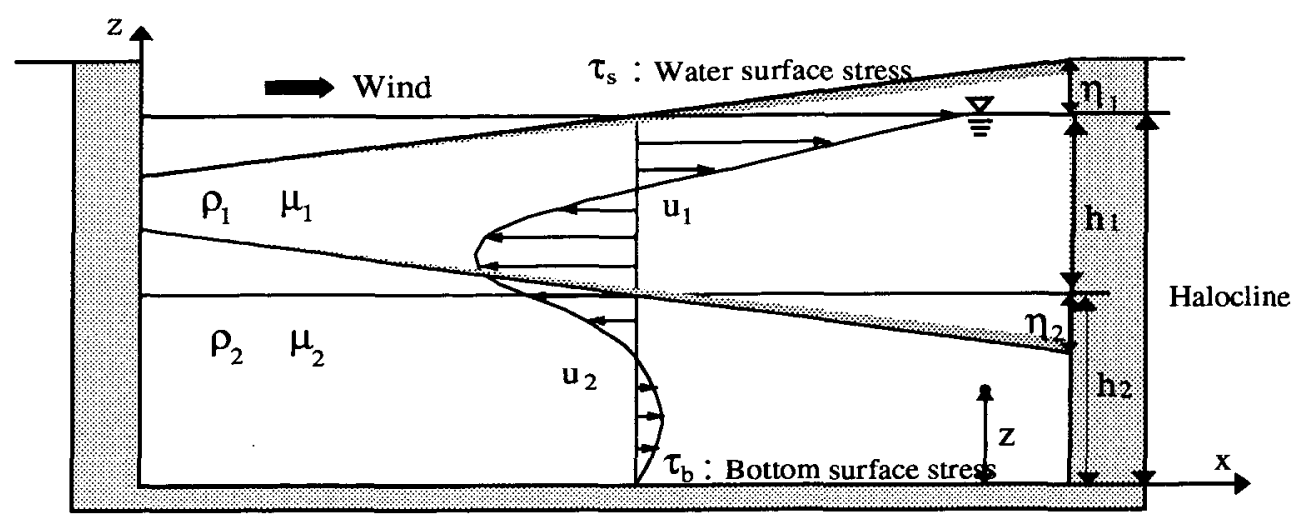

Fig. 8. Two-layer model of a brackish lake.

$\rho$ : Density $\left(\mathrm{g} \mathrm{cm}^{-3}\right), \mu$ : eddy viscosity $\left(\mathrm{g} \mathrm{cm}^{-1} \mathrm{sec}^{-1}\right), \eta$ : vertical displacement $(\mathrm{cm}), h$ : layer thickness $(\mathrm{cm})$ suffix $1:$ for upper layer, suffix 2 : for lower layer.

Our observation results of July, 1995 (Fig. 9) suggest that the halocline in the eastern (downwind) region (Pt. 2) descended with a phase lag of $2.5 \mathrm{hrs}$ (cross correlation coefficient $r=-0.47$ ) after a wind started to blow toward the east ; whereas the halocline on the upwind side (Pt. 1) rose with a phase lag of $3.0 \mathrm{hrs}(r=0.75)$ because of transient progress of water accumulation by wind blow.

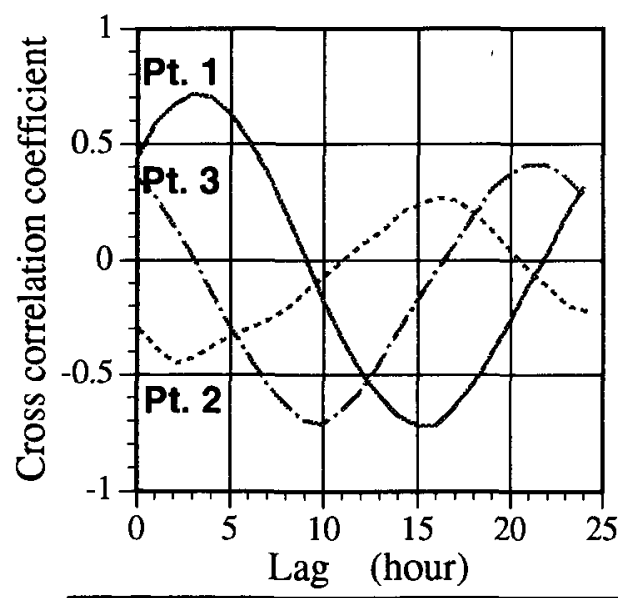

\section{Pt. 1 ..... Pt. 2 -.. Pt. 3}

Fig. 9. Cross correlation coefficient between the E-W component of wind velocity and change in the height of the halocline from 8 to 17 July 1995. 
Internal seiches caused by wind drift effects when a dominant wind blows toward the east over lakes such as Lake Nakaumi are clearly observed at points located in the eastern and western regions.

When we carried out a similar analysis in 1996 ; internal oscillations driven by wind drift effects were measured at Pts. 5 and 6 (Fig. 10).

Figure 11 shows that the halocline descent at Pts. 5 and 6 was most rapid 4.8 and 6.8 hours $(r=-0.85$ and -0.9$)$, respectively, after a wind started to blow.
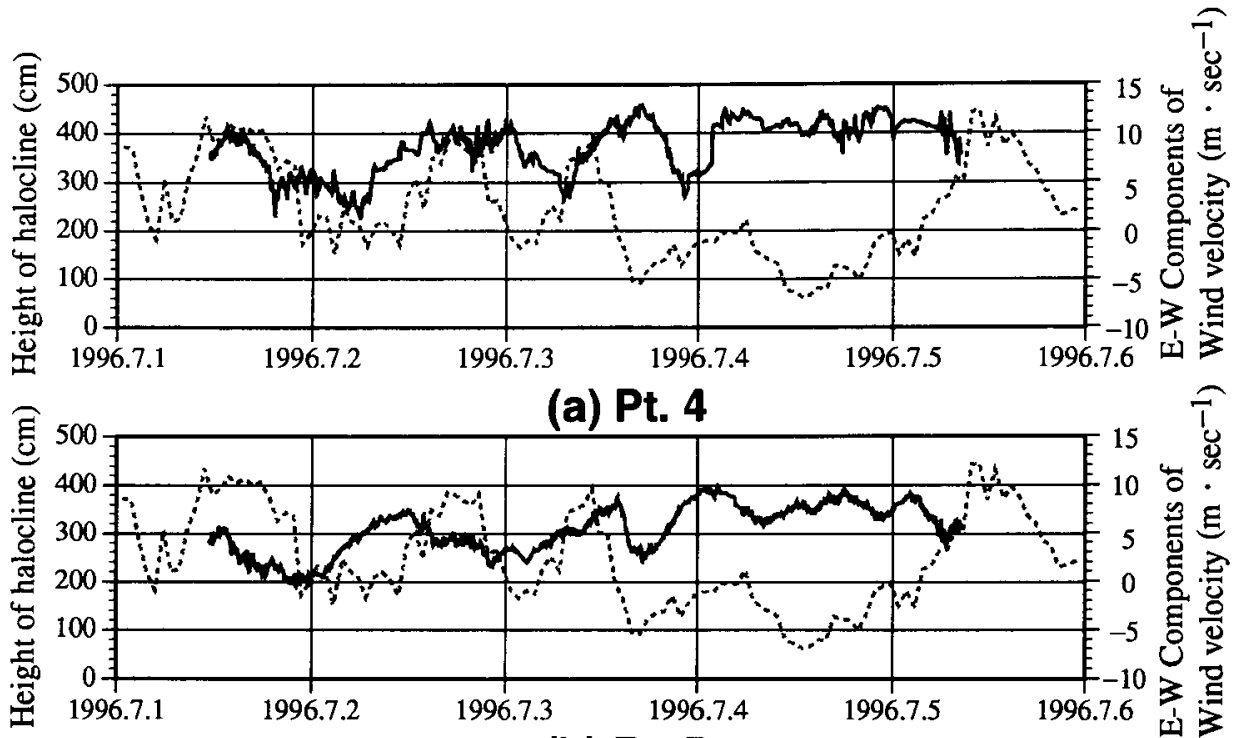

(b) Pt. 5

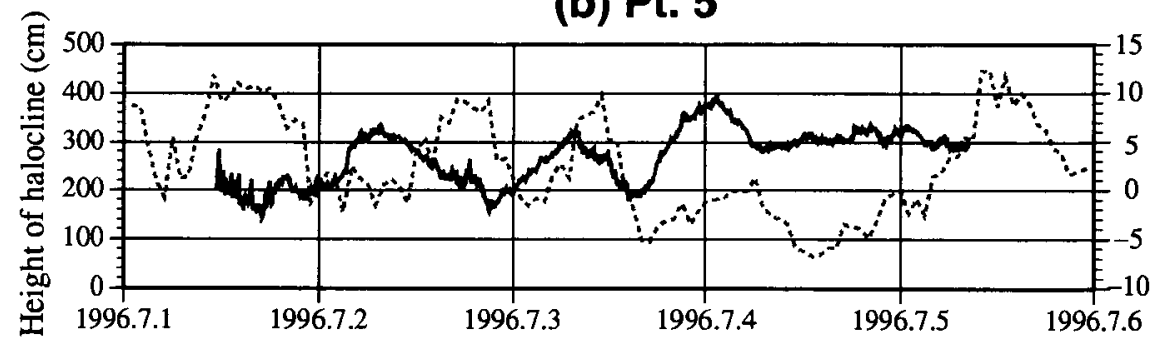

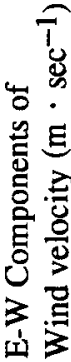

(c) Pt. 6

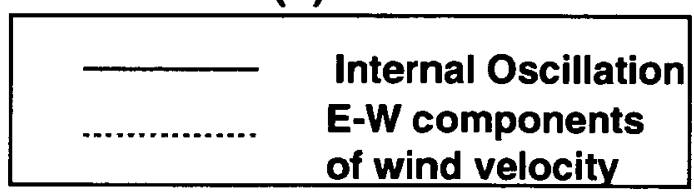

Fig. 10. Change in the height of the halocline from the bottom showing internal oscillation and the E-W components of wind velocity from 1 to 5 July 1996 .

(a) Pt. 4, (b) Pt. 5, (c) Pt. 6. 


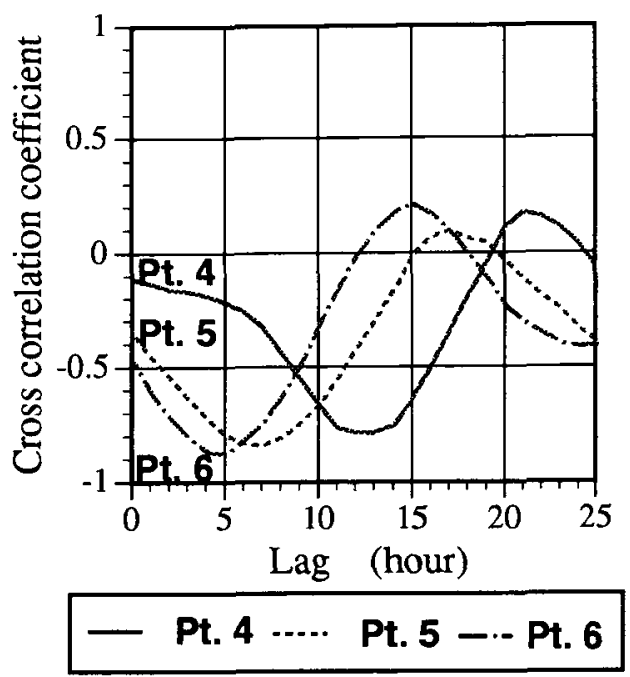

Fig. 11. Cross correlation coefficient between E-W component of wind velocity and change in the height of the halocline from 1 to 5 July 1996.

It is thought that the correlation between wind and internal oscillation in 1995 was low at Pt. 2 because that point is considerably offshore from the east coast and is affected by oscillations from Yonago Bay. Therefore, in 1996, the observation was carried out near the lake shore where the wind drift effect conspicuously appears, and a higher correlation coefficient was found than in 1995 .

As for the stationary state of the accumulation of the lake water, we used the two-layer lake model in two-dimensional space as shown in Figure 8 to estimate the inclination changes in the water surface as well as the halocline and wind-induced circulating current in the upper and lower layers.

The calculated current pattern is shown in the figure, and two stationary circulating currents appear in two layers.

In this calculation, we used

Kinematic equation

$$
\frac{\partial P}{\partial x}+\mu \frac{\partial^{2} u}{\partial z^{2}}=0
$$

The boundary conditions in the two-layer model are as follows:
(a) $u_{r}=V_{S}$
at $z=h_{l}+h_{2}$
(water surface)
(b) $u_{1}=u_{2}$ and $\mu_{1} \frac{\partial u_{1}}{\partial z}=\mu_{2} \frac{\partial u_{2}}{\partial z}$ at $z=h_{2}$
(interface)
(c) $u_{2}=0$
at $z=0$
(bottom)

The flow pattern for the stationary currents in the two layers needs the following conditions : 
(d) $\int_{h_{2}}^{h_{1}+h_{2}} u_{1} d z=0$

(upper layer)

(e) $\int_{0}^{h_{2}} u_{2} d z=0$

(lower layer)

In the Figure, suffix 1 and 2 are used for the geometrical or physical quantities in the upper and the lower layers, respectively, and $\mu$ denotes the eddy viscosity coefficients, $\mathrm{u}$ is current velocity, $\mathrm{h}$ is the thickness of layer, $P$ is the pressure and $V_{S}$ is surface current velocity.

We calculated the solution of steady state using the above boundary conditions.

The ratio of the water surface slope to the interface slope is given by the following equation using the two-layer lake model shown in Figure 8 :

$$
\frac{\eta_{1}}{\eta_{2}}=-\frac{\Delta \rho}{\rho_{1}} \cdot \frac{H+2 M}{H+\frac{M}{H}+2 M}
$$

where $\eta_{1}$ is the surface water rise near the downwind coast, $\eta_{2}$ is the interface descent near the downwind coast, $h_{1}$ and $h_{2}$ are the mean thicknesses of the upper and lower layers, $\rho_{1}$ and $\rho_{2}$ are the densities of the upper and lower layers $\left(\rho_{2}>\rho_{1}\right)$, respectively, $\Delta \rho \equiv \rho_{2}-\rho_{1}$ is the density difference between them, $H\left(=h_{2} / h_{1}\right)$ is the ratio of the thickness of the lower layer to that of the upper layer, $\mathrm{M}\left(=\rho_{2} \mu_{2} / \rho_{1} \mu_{1}\right)$ is the ratio of the eddy viscosity coefficient of the upper layer to that of the lower layer, and $\mu_{1}$ and $\mu_{2}$ are the eddy viscosity coefficients of the upper and lower layers, respectively.

It is known from other observations that the water surface level near Lake Nakaumi's downwind coast rises about $1.1 \mathrm{~cm}$ when the wind blows at $7.0 \mathrm{~m}$ $\sec ^{-1}$ (UEDA, 1996).

The displacement of the halocline generated by wind drift effects can be calculated from equation (2) using the actual water layer thickness and density distribution as follows : $\left(\eta_{1}=1.1 \mathrm{~cm}, \rho_{1}=1.011 \mathrm{~g} \mathrm{~cm}^{-3}, \rho_{2}=\right.$ $1.017 \mathrm{~g} \mathrm{~cm}^{-3}, h_{1}=450 \mathrm{~cm}, h_{2}=200 \mathrm{~cm}$ ). If we assume values for the ratio of the eddy viscosity coefficient in the lower layer to that in the upper layer, $M$, of $1 / 2,1 / 5,1 / 10,1 / 50$ and $1 / 100$, then the calculated displacement of the halocline, $\eta^{2}$, would be $277,243,221,194$ and $190 \mathrm{~cm}$, respectively.

The observed amplitude of halocline excursion, about $150 \sim 200 \mathrm{~cm}$ (see Figs. 7 and 10), is in good agreement with the theoretically calculated values for $M=1 / 10$ to $1 / 100$, which is of the same order as the ratio observed in Lake Biwa (Kumagai et al., 1987).

We found that in Lake Nakaumi, the halocline surface oscillates greatly with an amplitude of a few meters, even though wind drift alters the nearshore water surface level by only few centimeters.

\section{Propagation of internal waves}

How do internal waves generated by tidal or wind drift effects propagate in Lake Nakaumi?

Rotational internal waves such as internal Kelvin and Poincaré waves in 
freshwater lakes have recently been studied by MoRTIMER $(1980,1993)$ in Lake Geneva, and by CHIKITA et al. (1993) in Lake Kuttara.

Here, I have investigated the propagation characteristics of rotational internal waves in brackish Lake Nakaumi.

Assuming a two-layer model with a constant depth, the internal Rossby radius of deformation, $\mathrm{R}_{2}$, is given by the following equation (e.g., CSANADY, 1967) :

$$
R_{2}=\frac{C_{i}}{f}, \quad C_{i}=\left[g \varepsilon \frac{h_{1} h_{2}}{\left(h_{1}+h_{2}\right)}\right]^{1 / 2}
$$

where $\varepsilon=\left(\rho_{2}-\rho_{1}\right) / \rho_{2}$, g is the acceleration of gravity, $C_{i}$ is the internal wave phase speed, $\mathrm{f}$ is the Coriolis parameter $\left(\mathrm{f}=2 \Omega \sin \phi=8.44 \times 10^{-5}\right.$ $\mathrm{sec}^{-1}$ ) for Lake Nakaumi, $\Omega$ is the angular speed of the earth's rotation $\left(7.27 \times 10^{-5} \mathrm{sec}^{-1}\right)$ and $\phi$ is the latitude $\left.\left(35^{\circ} 27^{\prime}\right)\right)$.

Since the internal wave phase speed, $C_{i}$, in Lake Nakaumi in July, 1995 is calculated by equation (3) with the actual data for Lake Nakaumi ( $g=$ $9.8 \mathrm{~m} \mathrm{sec}^{-2}, h_{1}=4.0 \mathrm{~m}, h_{2}=2.5 \mathrm{~m}, \rho_{1}=1.012 \mathrm{~g} \mathrm{~cm}^{-3}$ and $\rho_{2}=1.016 \mathrm{~g}$ $\mathrm{cm}^{-3}$ ) to have been $24.4 \mathrm{~cm} \mathrm{sec}^{-1}$ and $R_{z}$ calculated from $C_{i}$ was $2.9 \mathrm{~km}$.

Similarly, using the actual values for Lake Nakaumi in July, 1996, $C_{i}$ is calculated to have been $35.1 \mathrm{~cm} \mathrm{sec}^{-1}$ and $R_{2}$ was $4.2 \mathrm{~km}$.

We calculated the ratio $P$ of lake width, b, to the internal Rossby radius of deformation, $R_{2}$, to evaluate the lake scale effect by the following equation :

$$
P \equiv \frac{b}{R_{2}}
$$

In Lake Nakaumi, the ratio $P$ was 5.5 and 3.8 with respect to the $16 \mathrm{~km}$ east-west distance, and 2.0 and 1.4 with respect to the $6 \mathrm{~km}$ north-south distance in 1995 and 1996, respectively (Table 1), and $P$ in Lake Nakaumi is greater than 1. For reference, the ratio $\mathrm{P}$ at the north basin of Lake Biwa was 7.6 and 3.2 , with respect to the roughly $20 \mathrm{~km}$ east-west distance $\left(R_{2}\right.$ was $2.4 \mathrm{~km}$ in May and $6.2 \mathrm{~km}$ in August in Lake Biwa) (ENDOH et al., 1995), suggesting the possibility of the development of internal Rossby waves.

\begin{tabular}{|c||c|c|}
\hline & $\begin{array}{c}\text { East-West } \\
\text { distance } \\
(16 \mathrm{~km})\end{array}$ & $\begin{array}{c}\text { North-South } \\
\text { distance } \\
(6 \mathrm{~km})\end{array}$ \\
\hline \hline $1995 / 7$ & 5.5 & 2.0 \\
\hline $1996 / 7$ & 3.8 & 1.4 \\
\hline
\end{tabular}

Table 1. The ratio of lake width, $b$, to the internal Rossby radius of deformation, $R_{2}$. 
Consequently, the propagation of internal waves such as Poincare or Kelvin waves affected by earth's rotation is possible.

The angular velocity, $\sigma_{n}$, of internal Poincare waves in a stratified lake can be obtained from a two-layer model as follows (e.g., Csanady, 1975 ; MORTIMER, 1980):

$$
\sigma_{\mathrm{n}}^{2}=f^{2}+C_{i}^{2}\left(\frac{n \pi}{b}\right)^{2} \quad n=1,3,5, \cdots
$$

where $\mathrm{n}$ is the mode number and $\mathrm{b}$ is the width of the lake.

Based on the spectrum analysis by FUJII et al. (1996), the dominant period of internal oscillations in Lake Nakaumi is $24 \mathrm{hrs}$, longer than the inertial period, $T_{i}$, of $20.4 \mathrm{hrs}\left(T_{i}=2 \pi / \mathrm{f}\right)$ and the period of internal Poincare waves, $T_{p}$, of about 17 hours calculated by equation (5) using actual values for Lake Nakaumi $\left(f=8.44 \times 10^{-5} \mathrm{sec}^{-1}, n=1, b=14,400 \mathrm{~m}\right.$, $\left.C_{i}=24.4 \mathrm{~cm} \mathrm{sec}^{-1}\right)$. Furthermore, from the phase lag shown in Figure 12, the internal waves seem to propagate rotating counterclockwise in contrast to the internal Poincare waves which rotate clockwise.

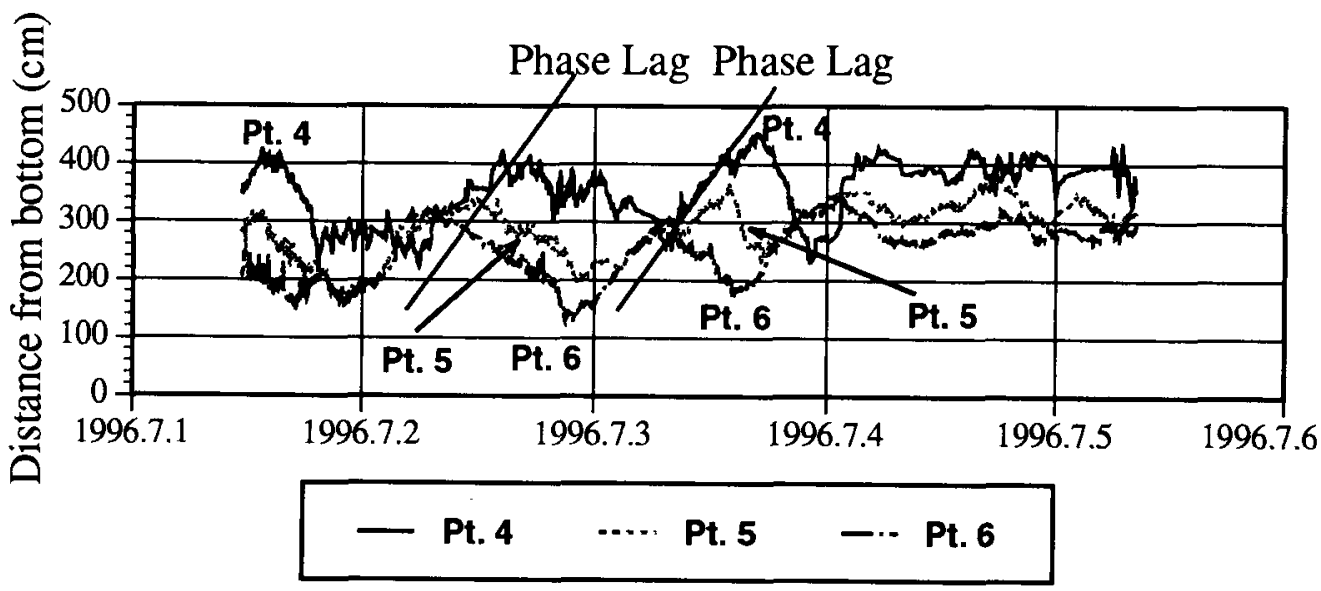

Fig. 12. Change in the height of the halocline from the bottom showing internal oscillation from 1 to 5 July 1996.

The angular velocity, $\sigma_{t}$, of a topographic internal wave in a stratified water region is derived as follows in the case where the bottom slope is uniform and time variation is slow (e.g., UNOKI, 1993) :

$$
\tanh \left(v h_{o}\right)=\frac{N^{2} s k \cos \varphi}{v f \sigma_{t}}
$$

Stabilized parameter

$$
v h_{0}=2 \pi\left(\frac{N}{f}\right)\left(\frac{h_{0}}{\lambda}\right) \quad v=\frac{N k}{f}
$$

where $h_{o}$ is the constant depth, $\mathrm{s}$ is the bottom slope, $k$ is the wave number $(=2 \pi / \lambda), f$ is the Coriolis parameter, $\lambda$ is the wave length, $N$ is the 
Brunt-Väisälä frequency, and $\varphi$ is the angle between the wave vector and the isobath.

The period of topographic internal waves calculated numerically by equation (6) and (7) using actual values for Lake Nakaumi $\left(\cos \varphi=1, h_{0}=5.4\right.$ $\left.\mathrm{m}, s=1 / 100, f=8.44 \times 10^{-5} \mathrm{sec}^{-1}, \lambda=28800 \mathrm{~m}, N=0.22 \mathrm{sec}^{-1}\right)$ is about 50 minutes, much shorter than the period of internal Kelvin waves obtained and calculated by our observations.

This conclusion suggests that in Lake Nakaumi the internal wave propagates as the internal Kelvin type, rotating counterclockwise ; I evaluated the correlation between the observed fluctuations at neighboring points to calculate the phase lag of wave propagation by cross correlation.

The phase lag in 1995 from Pt. 2 to Pt. 1 was $12 \mathrm{hrs} \mathrm{(cross} \mathrm{correlation}$ coefficient $r=0.3)$, that from Pt. 3 to Pt. 2 was $8 \mathrm{hrs}(r=0.4)$, and that from Pt. 1 to Pt. 3 was 6 hrs $(r=0.8)$ (Fig. 13). The phase lag in 1996 from Pt. 5 to Pt. 6 was 2.5 hrs $(r=0.8)$, and that from Pt. 4 to Pt. 5 was 4 hrs $(r=0.85)$ (Fig. 14).

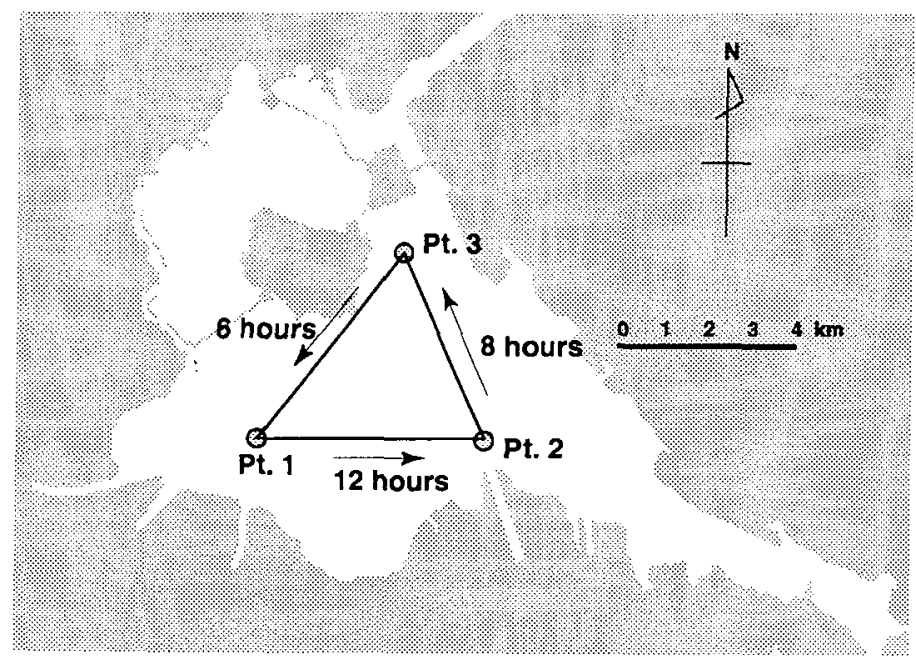

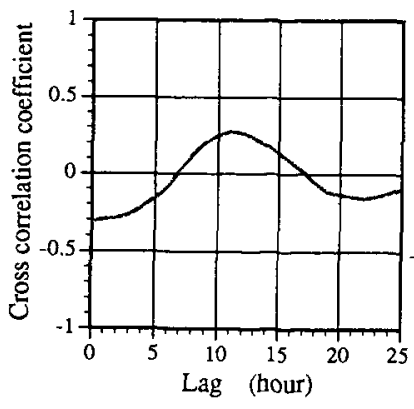

(a) Pt. $1 \rightarrow$ Pt. 2 (12 hours)

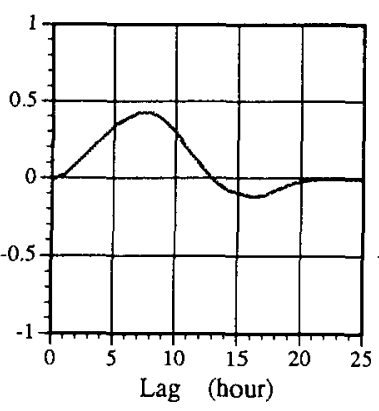

(b) Pt. 2 $\rightarrow$ Pt. 3 (8 hours)

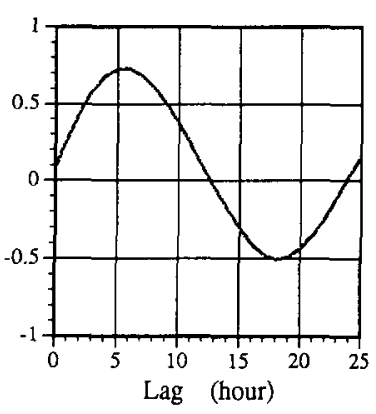

(c) Pt. 3 $\rightarrow$ Pt. 1 (6 hours)

Fig. 13. Time lag of internal oscillation between neighboring observation points in Lake Nakaumi from 8 to 17 July 1995.

(a) Pt. $1 \rightarrow$ Pt. 2, (b) Pt. $2 \rightarrow$ Pt. 3, (c) Pt. 3 $\rightarrow$ Pt. 1 . 


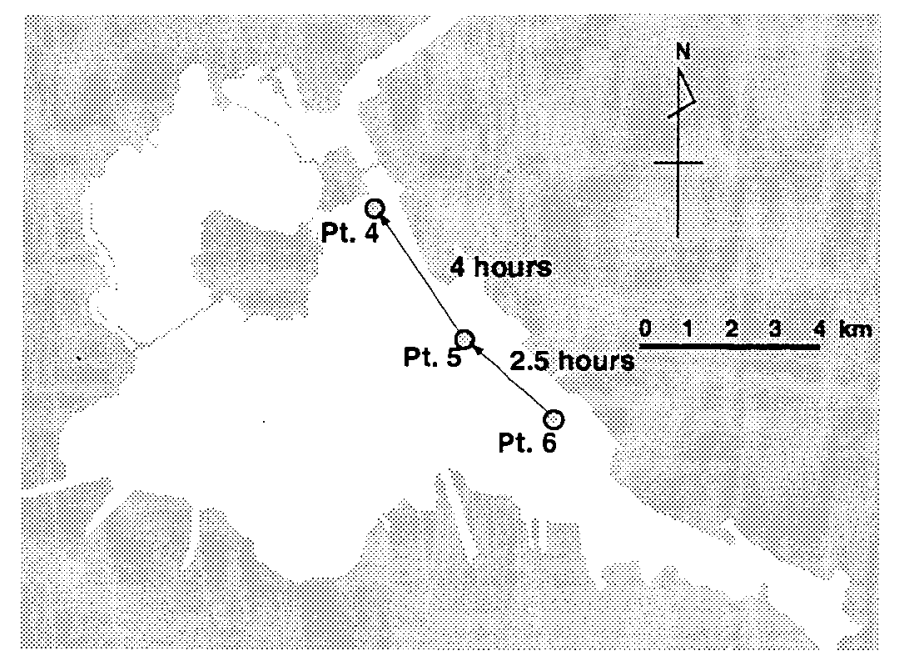

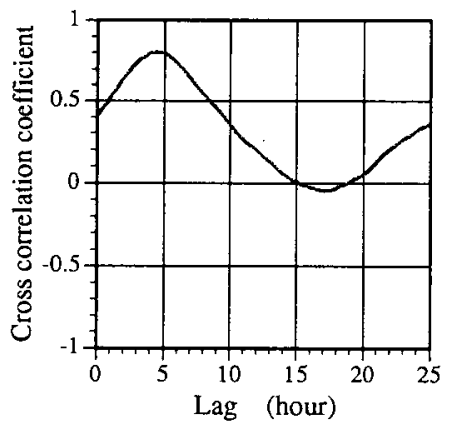

(a) Pt. 5 $\rightarrow$ Pt. 4 (4 hours)

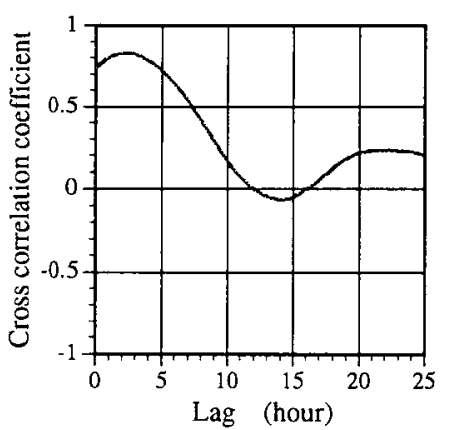

(b) Pt. 6 $\rightarrow$ Pt. 5 (2.5 hours)

Fig. 14. Time lag of internal oscillation between neighboring observation points in Lake Nakaumi from 1 to 5 July 1996.

(a) Pt. $5 \rightarrow$ Pt. 4, (b) Pt. 6 $\rightarrow$ Pt. 5 .

It is thought that the low correlation between neighboring points in the 1995 observation period because the variation in internal wave propagation speed near shore is large in observation areas where complex topography such as nonuniform depth, curved coastline, inlets such as Yonago Bay or inflowing rivers, affect internal wave propagation. Then, in 1996 we selected observation points along a short stretch of even shoreline where the distance between neighboring points can be set comparatively small and the depth is approximately uniform. From these observation points, we could obtain higher correlation results than in the 1995 observation. As shown in Figure 12, from our observation results in 1996 at Lake Nakaumi, we found the internal wave propagation rotating counterclockwise as an internal Kelvin wave type, and the propagation speed observed well agreed well with the one calculated.

We theoretically estimated the phase lag of internal Kelvin waves between neighboring points using internal phase speed $\left(24.4 \mathrm{~cm} \mathrm{sec}^{-1}\right.$ in 
1995 and $35.1 \mathrm{~cm} \mathrm{sec}^{-1}$ in 1996) obtained by Equation (3) from the stratification conditions observed in Lake Nakaumi. There was good agreement between the theoretically calculated and actual phase lag (Table 2), except for the lag from Pt. 2 to Pt. 1, which differed considerably from the one calculated.

\begin{tabular}{|c|c|c|c|}
\hline \multicolumn{3}{c|}{ (Unit : hour) } \\
\hline \hline $1995 / 7$ & Pt.1 $\rightarrow$ Pt.2 & 12 & 9.6 \\
& Pt.2 $\rightarrow$ Pt.3 & 8 & 8.6 \\
& Pt.3 $\rightarrow$ Pt.1 & 6 & 6.7 \\
\hline $1996 / 7$ & Pt.6 $\rightarrow$ Pt.5 & 2.5 & 2.2 \\
& Pt.5 $\rightarrow$ Pt.4 & 4 & 3.2 \\
\hline
\end{tabular}

Table 2. Observed and calculated time lag of internal oscillation between neighboring observation points.

Although the phase lag of 12 hrs from Pt. 2 to Pt. 1 was probably directly affected by internal seiches generated by wind drift, more careful observation and analysis are needed.

After an internal oscillation starts, internal waves in Lake Nakaumi seem to propagate counterclockwise along the lake coast in the manner of internal Kelvin waves.

\section{CONCLUSION}

This study quantitatively clarified the tidal and wind drift effects on internal oscillation and propagation characteristics of internal waves in Lake Nakaumi. The main conclusions are as follows :

(1) Tide conspicuously affects internal oscillation only in the limited area near the Nakaura water gate, the entrance to Lake Nakaumi. However, its influence is recognized clearly when the wind drift effect toward the northsouth direction is small.

(2) Wind drift conspicuously causes an internal oscillation near the coast; the amplitude of the vertical oscillation often reaches a few meters under ordinary wind speed.

(3) Observation results from July, 1995 and 1996 reveal that internal waves generated by both tidal oscillation and wind drift in Lake Nakaumi propagate counterclockwise, with larger periods than that of an inertial oscillation. This result suggests that the oscillation is of the internal Kelvin type rather than the Poincaré type. 
Some problems remain to be solved.

Seasonal changes in internal waves corresponding to various meteorological conditions should be measured by continuous field observations. Numerical simulations of the actual basin geometry and stratification conditions in the lake should be performed to more quantitatively clarify the relationship between the occurrence and propagation of internal waves with tidal and wind drift effects.

\section{ACKNOWLEDGEMENT}

The author would like to thank Prof. S. OKuDA of the Faculty of Science, Okayama University of Science for his helpful discussion and for checking the manuscript. Thanks are also due to Mr. M. NAKamuRA, head of the Experimental Fishery Station, Shimane Prefecture, for his assistance in conducting the field observations.

\section{REFERENCES}

Casanady, G. T (1967) : Large - Scale Motion in the Great Lakes, J. Geophys. Res., $72: 4151-4162$.

Casanady, G. T (1968a) : Wind-Driven Summer Circulation in the Great Lakes, J. Geophys. Res., $73: 2579-2589$.

Casanady, G. T (1968b) : Motions in a Model Great Lake Due to a Suddenly Imposed Wind, J. Geophys. Res., $72: 4151-4162$.

CASANAdy, G. T (1975) : Hydrodynamics of Large Lakes, Ann. Rev. Fluid Mech., $7: 357-386$.

Chikita, K., Y. Hosogaya and S. Natsume (1993) : Characteristics of Internal Waves in a Caldera Lake Introduced from Field Measurements: Lake Kuttara, Hokkaido, Jpn. J. Limnol., $54: 213-224$.

Endoh, S., Y. OKumura and I. OKamoto (1995) : Field Observation in the North Basin, p. 15-29. In S. Okuda (eds.), Physical Process in a Large Lake : Lake Biwa, Japan, American Geophysical Union.

FujII, T., T. UEdA, S. OKudA and K. YokoYama (1996) : Observation of Internal Oscillation in Brackish Lakes with a Neutral Buoy, Jpn. J. Limnol., 57 : 293 -304 .

Kumagai, K., H. MAeda and Y. Oonishi (1987) : Vertical Circulation in a Lake, Research Report from Lake Biwa Research Institute, No.86-A05 : 1-10 (in Japanese).

MoRTIMER, C. H. (1980) : Internal Motion and Related Internal Waves in Lake Michigan and Lake Ontario as Response to Impulsive Wind Stresses, Center for Great Lakes Studies Special Report, $37: 1-47$.

Mortimer, C. H. (1993) : Long Internal Waves in Lakes - Review of a Century of Research, Center for Great Lakes Studies Special Report, 42 : 1-60.

UEDA, T. (1996) : Effects of Wind Drift on Water level and Lake Current in Lake Nakaumi and Lake Shinji, Master thesis at Okayama University of Science (in Japanese).

UNOKI, S. (1993) : The wave and tide in stratified water region., p. 329-397. In 
S. Unoki (ed.), Coastal Oceanography, Tokai University Press. (in Japanese) .

Tomoyasu FuJII : Division of Science, Graduate School of Okayama University of Science, 1-1 Ridaicho, Okayama, 700 (藤井智康：干 700 岡山市理大町 1-1, 19 号館 岡山理科大学大学院理学研究科, 奥田研究室)

\title{
汽水湖一中海における内部波と潮汐・風の吹走との関連性 および内部ケルビン波の伝播
}

\author{
藤井智康
}

摘 要

中海では，潮汐，風の吹走によって振幅 2３mの内部波が頻繁に発生している。この内 部波による沿岸への高塩分水の這い上がりは中海沿岸部だけでなく大橋川を通しての宍道 湖の水質や生物環境にまで大きな影響を及ぼしていると考えられる。そこで，この水域の 潮汐や風の吹走が内部波に及ぼす影響について中立ブイを用いた観測結果に基づいて考察 した。解析結果として，中海においては潮汐の内部振動に対する影響は中浦水門付近のみ にはっきり現れ，水位変動との位相差 1 時間で内部振動が発生している。また，風の吹走 の内部振動に対する影響としては, 風の吹走より 2.5 3 時間くらい位相が遅れて塩分躍層 が傾斜している。この位相の遅れの定常的な解析は行われていないが，傾斜の向きは湖の 2 層モデルにおける風の吹走と躍層の昇降との関係とよく一致し，東西方向に風の吹走が 卓越する夏季の中海では中浦水門付近を除いて風の吹走作用が内部振動に及ぼす影響は潮 汐の影響よりも大きいと考えられる。

回転性の内部波の伝播は, 1995 年 7 月および 1996 年 7 月の内部振動の各ポイントでの 位相のずれから反時計回りに進行していることと周期が慣性周期より長いことおよびこの 時期の成層状態から計算される位相速度から求めた位相のずれが観測値に近いことから湖 内の内部波の進行は内部ケルビン波としての伝播であることが示された。 